\title{
Cluster Development as a Factor to Increase the Investment Attractiveness of the Region
}

\section{Elza Ivanovna Mantaeva}

\author{
Victoria Sergeevna Goldenova
}

\author{
Inna Valentinovna Slobodchikova
}

\author{
Federal State Educational Institution of Higher Professional Education "Kalmyk State University" \\ 358000 Russian Federation, Kalmyk Republic, Elista, Pushkina street, 11
}

\section{Doi:10.5901/mjss.2015.v6n5s2p358}

\section{Abstract}

Level of investment attractiveness of the region depends largely on the actions of regional authorities in the direction of a constructive dialogue with the business. There is a need to balance the interests of the state and business in order to increase the economic potential of the regions, the implementation of socio-economic interests of the population, attracting citizens to drive the development of its territory and the effective use of local resources, and as a consequence, increase the investment attractiveness of the regional economy. The article examines the socio- economic essence of clusters in the regional economy, offers ways of improving regional policies to encourage the creation of clusters in order to increase the investment attractiveness of the region.

Keywords: regional economy, cluster, investment attractiveness of the region.

\section{Introduction}

Economic policy has increased interest to the process of establishment and development of clusters in recent years. This huge interest to the process of clustering in the economy can be explained by positive experience of large-scale clustering in developed countries. This experience is a proof of evident stable efficiency of cluster approach in enhancing the competitiveness of the economy either in individual regions or in a country as a whole. Today cluster initiatives are a basic element of development strategies in the world economy. Consequently, the defining of the opportunity for using the experience of clustering in the Russian economy has become an urgent task (Mantaeva, E., E. Kurkudinova and A. Natyrov, 2013).

It is known that there are five main approaches to clustering economy. American approach is represented by M. Porter, M. Storper, M. Enright, S. Rezenfeld, P. Maskell, M. Lorentzen and is characterized by great focus on applied aspects of implementing ways for increasing the competitiveness of economic entities, while industrial and regional clusters are considered to be the core of competitiveness of individual countries and regions (Mantaeva, E., V. Goldenova and E. Kurkudinova, 2013, pp.66-73 ). British approach (J. Dunning, K. Freeman, H. Schmitz, J. Humphrey) suggests that the cause of clusters is the international division of labor between developed and developing countries, as well as forms and methods of organizing production. Scandinavian approach, whose founders B -O. Lundval, B. Johnson, B. Askhaym, A. Izaksen believe that the main driving forces of the clustering of the economy and as a consequence improving of its competitiveness are knowledge and learning (Mantaeva, E., V. Goldenova and E. Kurkudinova, 2013, pp.66-73 ). Swedish approach is based on the study of the relationships in big Swedish multinational corporations, the guarantee of the development of competitive success is the relationship between the ability to develop one sector and the ability to achieve progress in the other. Development should take place in stages or "vertical action" within one branch connected to other industries, and it will enable to achieve competitive advantages (Dahmen, E., 1950, pp.1919-1939).

French researchers Tolenado I. (Tolenado, J., 1978, pp.149-158) and D. Soulie (Soulie, D., 1989, pp.21-28) introduced a new scientific term "die" to describe nets of technologically interconnected economic sectors. The concept of "die" can be considered to be an important harbinger of the broader concept "clusters." The cause of the cluster Soulie and Tolenado see in the fact that on the one hand there are conditions for forming close technological ties among small producers and, on the other hand there is an opportunity to use national benefits by forming clusters of small enterprises in interrelated sectors of the economy in a given country.

It is known that the term "cluster" was introduced by M. Porter, who wrote that "... competitive national industries 
are not distributed uniformly throughout the economy, and are connected in what can be called a cluster consisting of industries in the country and are connected to each other by different links" (Porter, M., 1990, p. 131). From the point of view of theory it is necessary to tell that the term "cluster" is gradually losing its original meaning and becomes a brand used by regional authorities to attract foreign investment and improve the image of the region, etc.

\section{Main Part}

It is obvious, that regional authority should obtain a tool, which makes it possible to implement such plans and strategies and gives a considerable boost to regional economic growth, providing a significant ecological and social effect (Volkov, A., 2012, pp.1761-1766). Nowadays the cluster approach is one of the most popular instruments of state policy in developed countries. M. Porter has proven that this strategy is the most effective one for increasing the competitiveness of companies in domestic market as well as in the global market. Also he determined a direct correlation between the level of development of clusters in a given country and its standard of living.

Currently there are three main types of clusters (Mantaeva, E., V. Goldenova and E. Kurkudinova, 2013, pp.66-73):

- Clusters with regionally limited form of economic activity within the related sectors, usually tied to some academic institutions (research institutes, higher education institutions, etc.);

- Clusters with vertical production ties in narrow areas formed around the parent firms or major network companies, covering the processes of production, supply and distribution;

- Industry clusters in various kinds of production with a high level of aggregation (eg, "chemical cluster") or at an even higher level of aggregation (eg "aerospace cluster").

Characteristic features of the clusters are shown in Fig. 1.

It should be noted that in the context of the regional economy holding cluster policy is essential, as it will allow the potential to solve a number of problems (Table 1).

There must be four economic entities as participants of any cluster: enterprises, government agencies, educational and research institutions, and financial institutions.

Considering the prospects of establishing and development of cluster associations on the territory of Kalmyk Republic we think that regional authorities carry out a deliberate policy by creating and developing an agro-industrial cluster. This is due to the fact that Kalmyk Republic has agrarian economy. In this case the main indicators of socioeconomic development: gross regional product per capita, cash income and the level of employment, the volume of investments to the economy and others, the republic ranks the last among other regions of the Russian Federation. So, in terms of GDP per capita republic is on the 78th place among the regions of Russia (Regions of Russia. Socio-economic indicators, 2012). Despite the absolute increase in 20 times in the period of 1998 and2011, the gross regional product of Kalmyk Republic per capita is just over $50 \%$ of the index for the Southern Federal District and the third of the national average.

\begin{tabular}{|c|c|}
\hline geographical feature & $\begin{array}{l}\text { formation of clusters associated with a particular teritory, } \\
\text { ranging from local and regional to global clusters }\end{array}$ \\
\hline horizontal feature & $\begin{array}{l}\text { largest duster combines several industrial sectors or } \\
\text { industries on an equal footing }\end{array}$ \\
\hline vertical feature & $\begin{array}{l}\text { dusters always have a hierarchical relationship or production } \\
\text { stages of the innovation process }\end{array}$ \\
\hline lateral feature & $\begin{array}{l}\text { economies of scale of production, leads to new opportunities } \\
\text { as a result of combining cluster members to the cluster of } \\
\text { different sectors of the same industry }\end{array}$ \\
\hline technologieal feature & $\begin{array}{l}\text { duster members are connected to the same production } \\
\text { technology }\end{array}$ \\
\hline focal feature & $\begin{array}{l}\text { cluster members, usually centered around one center, in which } \\
\text { can be a leading large company, a research institute or } \\
\text { university) }\end{array}$ \\
\hline qualitative feature & $\begin{array}{l}\text { the merger of the participants in the cluster oceurs } \\
\text { improvement in all areas of their cooperation, enhance the } \\
\text { competitiveness of each participant, and improving the } \\
\text { economic situation of the entire community }\end{array}$ \\
\hline
\end{tabular}

Figure 1. Characteristic features of the clusters.

As it was mentioned above, there is no doubt that agriculture plays an important role in the regional economy. In the structure of sectors agriculture provides a significant increase in gross regional product, as well as such industries as oil and gas extraction, power generation, tourism and education. The Government of Kalmyk Republic established "Center 
of cluster development, investment and information-consulting service agribusiness". At the same time we think that the economy of Kalmykia needs to create not only agro-industrial cluster, but also several others.

Table 1. Problems of regional economy which can be solved with the help of cluster approach

\begin{tabular}{|l|l|}
\hline Problems of regional economy & Solutions of problems with the help of cluster approach \\
\hline Low level of competition & $\begin{array}{l}\text { development of competition, which will be the driving force to enhance the } \\
\text { competitiveness of enterprises through support for innovative firms and the creation of } \\
\text { a favorable environment in which weaker companies could also increase its } \\
\text { competitiveness }\end{array}$ \\
\hline $\begin{array}{l}\text { Low level of innovation capacity of } \\
\text { enterprises }\end{array}$ & $\begin{array}{l}\text { developing and enhancing innovation capacity of enterprises, particularly small and } \\
\text { medium, as they, as practice shows, create cluster initiatives and as a result are } \\
\text { combined into regional and local clusters }\end{array}$ \\
\hline $\begin{array}{l}\text { Focusing on the implementation of } \\
\text { macro regional economic policy }\end{array}$ & $\begin{array}{l}\text { cluster policy in the main emphasis should be placed on a microeconomic approach } \\
\text { that takes into account local peculiarities of development and functioning and to } \\
\text { develop targeted interventions to accelerate the development and competitiveness of } \\
\text { enterprises on the basis of not only the existing (natural resources, etc.), but also } \\
\text { produced factors of production (a highly skilled workforce, available infrastructure, etc.) }\end{array}$ \\
\hline $\begin{array}{l}\text { Lack of productive dialogue between } \\
\text { the public-private partnership }\end{array}$ & $\begin{array}{l}\text { cluster policy should be based on public-private partnership, as it is an effective } \\
\text { interaction between the regional authorities, the business community and academic } \\
\text { institutions will promote efficiency in joint ventures }\end{array}$ \\
\hline
\end{tabular}

It should be emphasized that the economy of Kalmyk Republic is conditionally divided into three zones of advanced development (The concept of socio-economic development of the Republic of Kalmykia on the period up to 2015, p.106]:

- Development Zone of beef cattle and fodder - the territory of the Octyabrsky, Maloderbetovsky, Sarpinsky, Ketchenerovsky, Tselinnyi, Yustinsky, Gorodovikovsky and Yashaltinsky areas.

- Development Zone of gas processing industry - the territory of the Lagan and Chernozemelsky areas.

- The area of energy development and construction industry - Yashkulsky, Iki Burulsky, Priyutnensky areas (Soulie, D., 1989, pp.21-28).

Depending on the specialization of the territorial districts of Kalmyk Republic as well as the contribution of the relevant industries in the gross regional product of the possible creation of regional clusters such as (The concept of socio-economic development of the Republic of Kalmykia on the period up to 2015, pp.106-107]:

- agro-industrial cluster,

- oil and gas cluster,

- energy cluster,

- Education Cluster,

- tourism and recreation cluster.

Note that, for example while creating and developing agro-industrial cluster it is necessary to take into consideration that this aggregated cluster should contain several smaller subclusters, such as livestock, crop and agricultural processing subcluster. Moreover, the development of agricultural processing allows subclusters to develop not only traditional sectors of agriculture of Kalmyk Republic but also gives an impetus to the development of poor developed sector. The development of agro-industrial cluster needs:

- investment in retooling agricultural industries;

- organization of the agricultural market infrastructure;

- improvement of land legislation and improvement of agricultural development in the Republic of Kalmykia.

The oil and gas cluster of Kalmyk Republic requires restructuring of oil and gas industries on the basis of high-tech industries created with the help of Russian researchers.

Regional government should promote the development of wind potential by using small private wind turbines along with the operation of solar panels, which is one of the most effective ways to generate electricity from the environment. Therefore, regional authorities should create favorable conditions for solar energy and wind power potential.

Education Cluster should be a set of interrelated institutions of higher and secondary vocational education, which are combined together on a sectoral basis as well as partnerships with the industry. We think that Kalmyk State University should play the role of a leading center for training and retraining of personnel for knowledge-intensive production, which is the main source and the source of innovation and providing of new competitive technologies and developments.

As to tourism and recreation cluster, the regional authorities should implement the development of advertising and 
information support for tourism, establish a system of state regulation and support of tourism activities; implement personnel policies and scientific and methodological support of the tourism industry, to ensure the promotion of tours around Kalmyk Republic in the Russian and international tourism market.

Creation and development of the above clusters allow industries of the Kalmyk Republic to become more competitive, not only regionally, but also on the national market. Subjects cluster will not only invest in specialized research and the development of related technologies, create new jobs, but also to develop the infrastructure of Kalmyk Republic, so will manifest synergies from the creation of the cluster structure of the economy that will allow regional business survive in the competition not only regional and national markets, but also in globalized markets. For regional authorities clusters will serve as points of growth of the internal market and to ensure the promotion of their products and services on national and international markets.

\section{Conclusions}

We can offer the following main directions of the state policy on the development of clusters that should be implemented jointly by regional authorities and local self-government:

1. Expansionary policy, including:

- The development of engineering and transport infrastructure of the Republic of Kalmykia, including housing, implemented with the objectives of the development of clusters, which requires both private and public investment;

- Increasing the efficiency of higher and vocational education, and to create conditions for fruitful cooperation between companies and educational institutions;

- Reduction of administrative barriers;

- Promotion of socially responsible investing (Mantaeva, E., V. Goldenova and V. Chudidov, 2011, pp.176180);

- Providing tax incentives provided by the legislation.

2. Administrative policy, consisting in granting preferences to support relevant projects depending on the membership involved in their implementation companies to a particular cluster.

3. Institutionalized, suggesting the formation of a specialized organization of cluster development, responsible for strategic planning activities cluster development, the establishment of effective communication between the cluster actors and stimulate the strengthening of cooperation between them.

Each of the proposed areas of development clusters, taking into account features of separation of powers must be implemented at both the federal and the regional and local levels.

\section{Acknowledgements}

The study was supported by the Russian Humanitarian Foundation as part of the research project "Study of the effectiveness of state support of business as a factor to increase the investment attractiveness of the region", the project \# 14-12-08001.

\section{References}

Dahmen, E., 1950. Entrepreneurial Activity and the Development of Swedish Industry, pp.1919-1939. Stockholm.

Mantaeva, E., E. Kurkudinova and A. Natyrov, 2013. Agriculture cluster in the regional economy. Journal of Agricultural Sciences, 2013.

Mantaeva, E., V. Goldenova and E. Kurkudinova, 2013. Cluster as a factor of competitiveness of the regional economy. Modern Economy: Problems and Solutions. 11: pp.66-73.

Mantaeva, E., V. Goldenova and V. Chudidov, 2011. Model of interaction between government and business in the implementation of social responsibility. Herald Kalmyk Institute for Humanities Research. 2: pp.176-180.

Porter, M., 1990. Competitive Advantage of Nations. Free Press.

Regions of Russia. Socio-economic indicators, 2012. GKS.

Soulie, D., 1989. Filieres de Production et Integration Vertical. Annales des Mines. Janvier: pp.21-28.

The concept of socio-economic development of the Republic of Kalmykia on the period up to 2015 (approved by the Government of the Republic of Kalmykia of 30.05.2011 \#152).

Tolenado, J., 1978. Propjs des Filires Industrielles. Revue d'Economie Industrielle. V. 6. 4: pp.149-158.

Volkov, A., 2012. Cluster Policies in Energy Efficiency Management in Regional Innovative Strategy of Sustainable Development. European Researcher. Vol. (32), 10-2: pp.1761-1766. 